\title{
KAIZEN IMPLEMENTATION CONTEXT AND PERFORMANCE
}

\author{
UDC: 005.6 \\ Original Scientific Paper \\ Vesna SPASOJEVIĆ BRKIĆ ${ }^{1}$, Branislav TOMIĆ ${ }^{2}$, Martina PERIŠIĆ ${ }^{1}$, \\ Aleksandar BRKIĆ ${ }^{3}$ \\ ${ }^{1}$ University of Belgrade, Faculty of Mechanical Engineering, Kraljice Marije 16, 11000 Belgrade, \\ Republic of Serbia \\ E-mail: vspasojevic@mas.bg.ac.rs \\ ${ }^{2}$ Bombardier Aerospace, Toronto, Canada \\ ${ }^{3}$ University of Belgrade, Faculty of Mechanical Engineering, Innovation Center, Kraljice Marije 16, 11000 \\ Belgrade, Republic of Serbia \\ Paper received: 12.02.2020.; Paper accepted: 21.04.2020.

\begin{abstract}
Quality improvement implies the application of quality tools, techniques, methodologies and applications. Through their proper use, the desired level of quality can be achieved and then continuously improved. Kaizen implementation could be of particular significance. This paper covers a survey done at a large multinational company supply chain (sample size 200 companies) and analyses the application of Kaizen and contextual and performance variables using correlation analyses. Survey results showed that the implementation of Kaizen in the company increases performance indicators, especially in the area of quality. Also, Kaizen application is positively correlated to variables such as organizational goals and objectives, the level of formalization, reward system, conflict management and progress and development of employees.
\end{abstract}

Key words: Kaizen; Context; Performance.

\section{INTRODUCTION}

Today's business successes and even business survival mean constant evolution and changes. Quality improvement initiatives are the key part of this evolution, and they are often revolutionary processes which lead to success. Unfortunately, there are also many examples of poorly designed quality improvement programs that failed to produce the desired results. Success cannot be guaranteed by copying others, using short-term techniques, or by applying some predetermined model created from theoretical principles or proven successful in the practice of some other organizations. Every organization is unique in its products or services, strategy, management style and present organizational cultures. Only by recognizing these specifics, the quality improvement program that is ready to tackle the fundamental and unique obstacles in the system and over time provide support for all relevant elements in the system, with the aim of creating a constant change for the better, can be developed.
With this in mind, probably the most important business activities determinant of a production system is the corresponding product quality.

The achievement of the desired quality process is a long and hard labor. Planning, control, assurance, management and quality improvement represent this unbreakable chain of realization of the required quality or service. In that chain, which is a dynamic process, the process of continuous improvement represents the engine of the whole system in that continuous spiral towards the creation of increasingly better final product or service.

Continuous quality improvements are processes that are tasked to ensure the continuous development and improvement of all segments of one or more processes. When the development of the entire organization is required, the most important first step is to establish the identification of all processes and the mechanisms for measuring 
key variables. Basically, continuous improvements require the first and foremost, (Westcott, 2007):

- management support,

- feedback,

- clearly defined process ownership,

- involvement of all employees,

- accurate measurements and

- detailed analysis.

Successful quality improvement consists of continuous improvements, corrective measures and innovation equally, (Peterson, \& Reid, 1999). Also, any successful quality improvement initiative as a prerequisite for all prerequisites requires the involvement and support of management and leadership, (Lagrosen, \& Lagrosen, 2003). Quality improvement must equally capture the operational as well as the strategic level in the observed process or system, (Kannan, Tan, Handfield, \& Ghosh, 1999). Improvement of the quality strategy is an integral part of the overall, (Spasojević Brkić, Klarin, \& Ivanović, 2009). Problem identification is the first basic step for any change even for continuous quality improvements, (Spear, \& Bowen, 1999). Principles of quality management include the use of quality tools and methodologies, (Spasojević Brkić, et al., 2009). Continuous quality improvements are imperative in today's world of contingent and unpredictable changes that strongly and multidimensionally affect the business environment, (De Feo, \& Barnard, 2003).

Merrill (2009) identifies ten major barriers to achieving the desired quality:

1. poor communication,

2. unclear and changing requirements,

3. lack of support from top management,

4. poor employee motivation and morale,

5. insufficient training,

6. incompetent suppliers,

7. non-compliance regulations,

8. quick solutions,

9. lack of time and

10.unclear process ownership.

Quality improvement is done through the application of quality tools, techniques, methodologies and applications, (Spasojevic Brkic et al., 2009; Tomic, \& Spasojević Brkić, 2011). Through their proper use, the desired level of quality can be achieved and then continually improved. Kaizen implementation can be particularly significant.

\section{METHODOLOGY}

Kaizen (Kaizen - a Japanese word synonymous for - with continuous incremental improvements) represents mostly small, almost imperceptible improvements rather than rapid and visible at the organization level.

Each employee, as a part of his or her engagement with the organization, continually advances processes. It is important that every employee, as a part of his or her engagement with the organization, continually advances processes that are in his or her competence or in which he or she actively participates. The total sum of such micro improvements actually has an effect on the macro level and improves the overall organization over time.

The quality improvement that in its basis contains small, incremental improvements is named Kaizen and it is shown in Figure 1.

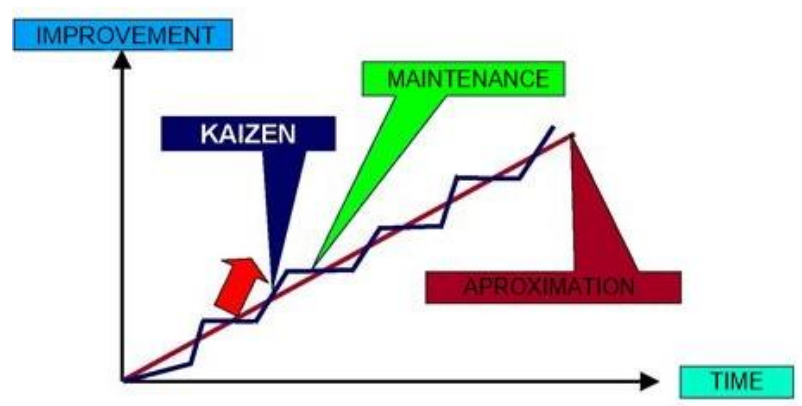

Figure 1: Kaizen-small improvements over time

Multiple previous studies emphasize that Kaizen's continued operation is conducive to building and maintaining manufacturing companies' competitive advantages, (Yamaguchi, \& Kono, 2017). Bateman (2003) has distinguished that administration approach, which has "liberal culture" and "energy" towards changes, will, in general, build up a positive Kaizen culture in the association. What's more, powerful correspondence and information from the executives are other, additional, critical elements to actualize Kaizen effectively, (Pagell, 2004). The presence of critical thinking groups, for example, quality circles and cross practical gathering cooperating to actualize Kaizen are likewise seen as an impetus towards Kaizen usage, (Marin-Garcia, Pardo del Val, \& Bonavia, 2008). Past analyses likewise show that worker's strengthening is imperative to the accomplishment of Kaizen usage, (Bessant, 2000; Liker, \& Hoseus, 2008; Womack, \& Jones, 2003). 
Furthermore, the organizational culture should motivate individuals to participate in small improvements initiatives proposed by their representatives, (Maarof, \& Mahmud, 2016). Mendez and Vila Alonso (2018) point out that representative new propensities, convictions and emotions are the requirement for successful Kaizen execution. Authors McLoughlin and Miura (2017) also point out the importance of organizational culture dimensions for successful Kaizen application and further companies' performance.
According to that idea, Tomic et al. (2017) propose statistically significant organizational culture and performance dimensions, important for Kaizen implementation, as in Table 1. Those constructs are going to be undergone to descriptive statistics and correlation analysis in this survey with aim to draw conclusions on predictors of Kaizen implementation together with its influence on performance.

Table 1: Dimensions and its descriptions (Tomic et al., 2017)

\begin{tabular}{|c|c|}
\hline Dimension & Description \\
\hline Focus on Objectives and Goals & $\begin{array}{l}\text { The level of organizational focus and accomplishment of its objectives } \\
\text { and goals }\end{array}$ \\
\hline Level of Formalization & $\begin{array}{l}\text { The level of documented procedures and other documents in } \\
\text { organization }\end{array}$ \\
\hline Reward System & $\begin{array}{l}\text { The level of stimulation of employees in terms of monetary and non- } \\
\text { monetary prizes }\end{array}$ \\
\hline Conflict Management in Organization & $\begin{array}{l}\text { The level of effective conflict management between individuals / } \\
\text { groups }\end{array}$ \\
\hline $\begin{array}{l}\text { Knowledge and Competitiveness of } \\
\text { Employees }\end{array}$ & $\begin{array}{l}\text { The level of education and practical experience of the employees in the } \\
\text { organization }\end{array}$ \\
\hline $\begin{array}{l}\text { Progress and Development of } \\
\text { Employees }\end{array}$ & The level of promotion and investment in its employees \\
\hline Primary Focus of the Organization & $\begin{array}{l}\text { The level of organizational orientation toward internal or external } \\
\text { influencing factors }\end{array}$ \\
\hline Kaizen & The level of practice of the incremental improvements in all processes \\
\hline Market and Financial Performances & $\begin{array}{l}\text { - Increasing the number of customers over time } \\
\text { - Profit increase } \\
\text { - Increasing the marker share } \\
\text { - Stable position on the market } \\
\text { - Increasing the return of investment }\end{array}$ \\
\hline Operational Performances & $\begin{array}{l}\text { - Productivity increase } \\
\text { - Deliveries on time } \\
\text { - Cost reduction over time } \\
\text { - Successful waste reduction program } \\
\text { - Reduction of the cycle times } \\
\end{array}$ \\
\hline Employees Performances & $\begin{array}{l}\text { - Increasing employees satisfaction over time } \\
\text { - Decreasing the absenteeism } \\
\text { - Increasing the salaries and benefits } \\
\text { - Dedication of employees } \\
\text { - Decreasing the employee turnover rate }\end{array}$ \\
\hline $\begin{array}{l}\text { Investment and Development } \\
\text { Performances }\end{array}$ & $\begin{array}{l}\text { - Investment in research and development } \\
\text { - The expansion of production capacities } \\
\text { - Increasing the number of employees } \\
\text { - Investment in process / product innovation } \\
\text { - Improvement of technical aspects of processes / products }\end{array}$ \\
\hline Quality Performances & $\begin{array}{l}\text { - Decreasing the number of nonconforming products } \\
\text { - Continual processes / products improvement } \\
\text { - Reduction of processes / products variability } \\
\text { - Decreasing the cost of poor quality } \\
- \text { Adequately addressing the processes with documented procedures }\end{array}$ \\
\hline Customer Satisfaction Performances & - Increasing the Customer satisfaction \\
\hline
\end{tabular}




\begin{tabular}{|c|l|}
\hline Dimension & \multicolumn{1}{c|}{ Description } \\
\hline & - Decreasing the number of customer complaints \\
& - Decreasing the number of warranty claims \\
& - The existence of loyal customers \\
& - The importance of the voice of the customers \\
\hline
\end{tabular}

\section{RESULTS}

The survey is focused to a large multinational company with 76,400 employees, specialized in aircraft, rail transportation equipment and systems, and motorized consumer products manufacturing. End-product organizations face the challenge of assuring the quality of, and integration with, product purchased from suppliers throughout the world and at all levels within the supply chain, (Tomić, Spasojević-Brkić, \& Klarin, 2012). Accordingly, focused company has successful collaboration with large number of reliable and steady suppliers and sample in this survey contains information form supply chain of subjected company.
To collect data in this survey, an e-mail questionnaire was sent to randomly chosen 500 companies in a supply chain. Questionnaire contained the variables chosen from literature in research framework, measured in Likert scale with end points of "strongly disagree $(=1)$ " and "strongly agree (=5)". A total of 200 answers are received by this survey.

Table 2 shows the descriptive statistics of the variables studied, and Table 3 shows correlation between the application of Kaizen and other variables - contextual and performance.

Table 2: Descriptive statistics on the variables studied

\begin{tabular}{|l|c|c|c|c|c|c|c|c|c|}
\hline & $N$ & Range & Minimum & Maximum & Mean & $\begin{array}{c}\text { Std. } \\
\text { Deviation }\end{array}$ & Variance & Skewness & Kurtosis \\
\hline $\begin{array}{l}\text { Organizational Goals / } \\
\text { Objectives }\end{array}$ & 200 & 3.00 & 1.80 & 4.80 & 3.6340 & .58322 & .340 & -.788 & .337 \\
\hline The Level of Formalization & 200 & 3.20 & 1.80 & 5.00 & 3.6030 & .74334 & .553 & -.710 & -.322 \\
\hline Reward System & 200 & 3.00 & 1.80 & 4.80 & 3.6270 & .51692 & .267 & -1.322 & 2.006 \\
\hline Conflict Management & 200 & 2.80 & 1.80 & 4.60 & 3.3900 & .55628 & .309 & -.329 & -.331 \\
\hline $\begin{array}{l}\text { Knowledge and } \\
\text { Competitiveness }\end{array}$ & 200 & 2.40 & 2.00 & 4.40 & 3.2250 & .48905 & .239 & -.140 & -.185 \\
\hline $\begin{array}{l}\text { Progress and Development of } \\
\text { Employees }\end{array}$ & 200 & 4.00 & 1.00 & 5.00 & 3.4600 & .87856 & .772 & -.968 & .419 \\
\hline $\begin{array}{l}\text { Primary Focus of the } \\
\text { Organization }\end{array}$ & 200 & 3.40 & 1.20 & 4.60 & 3.0250 & .63053 & .398 & .090 & -.339 \\
\hline Kaizen & 200 & 4.00 & 1.00 & 5.00 & 3.9633 & .73653 & .542 & -1.124 & 1.678 \\
\hline $\begin{array}{l}\text { Market and Financial } \\
\text { Performances }\end{array}$ & 200 & 3.00 & 1.80 & 4.80 & 3.4050 & .57114 & .326 & -.513 & -.105 \\
\hline Operations Performances & 200 & 2.60 & 1.80 & 4.40 & 3.3250 & .51371 & .264 & -.321 & -.203 \\
\hline Employees Performances & 200 & 2.80 & 2.00 & 4.80 & 3.4230 & .56254 & .316 & -.499 & -.273 \\
\hline $\begin{array}{l}\text { Investment and Development } \\
\text { Performances }\end{array}$ & 200 & 2.60 & 2.00 & 4.60 & 3.2590 & .49795 & .248 & -.037 & -.281 \\
\hline $\begin{array}{l}\text { Quality Performance } \\
\text { Customer Satisfaction } \\
\text { Performances }\end{array}$ & 200 & 3.40 & 1.40 & 4.80 & 3.6480 & .67407 & .454 & -1.060 & .711 \\
\hline
\end{tabular}


Table 3: Correlation analysis between observed variables $(p=0.000)$

\begin{tabular}{|c|c|c|c|c|c|c|c|c|c|c|c|c|}
\hline & 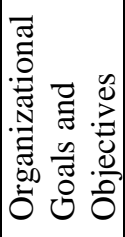 & 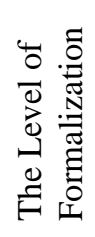 & 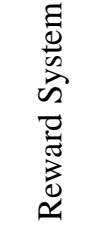 & 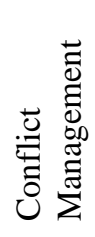 & 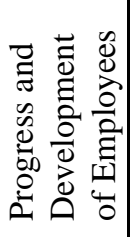 & 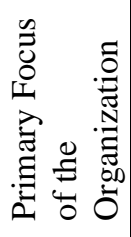 & 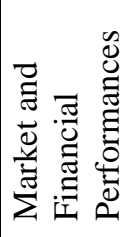 & 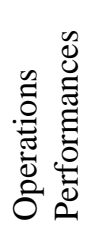 & 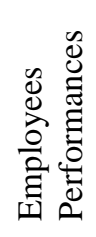 & 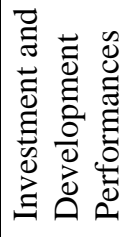 & 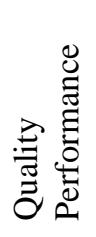 & 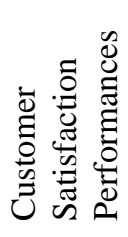 \\
\hline 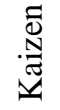 & 0.566 & 0.793 & 0.616 & 0.510 & 0.532 & -0.266 & 0.631 & 0.194 & 0.480 & 0.485 & 0.843 & 0.676 \\
\hline
\end{tabular}

\section{DISSCUSSION}

Survey results, obtained on sample size of 200 companies in multinational supply chain, as in tables 2 and 3, show that the construct with highest value is the Kaizen implementation and it is followed by quality performance, while those two constructs also have the highest correlation coefficient. Accordingly, in that way it is proved that Kaizen and quality performance are interrelated. In that manner is proved that small, almost imperceptible improvements are very important in quality management field, with aim to obtain good quality performances. The construct with the lowest mean values is the primary focus of organization and there is the lowest, negative correlation between Kaizen and focus. It means that companies which implement Kaizen do not have strong external focus, but rather point out to internal processes.

Also, it is evident that implementation of Kaizen in the company increases performance indicators. There is the highest mean value on quality performance, followed by employees performances, market and financial performances, customer satisfaction performances, operations performances and finally by investment and development performances. There is the highest correlation on quality management performance and the lowest on organizational performance with Kaizen implementation. If all constructs are seen, beside performance, there is the highest correlation between Kaizen and the level of formalization, which means that Kaizen implementation is managed in a very formalized manner.

In total, it is evident that Kaizen is related to both organizational culture context and performance, as supposed by previous research and according conclusions on posed hypothesis are to be made.

\section{CONCLUSION}

According to correlation results, it can be concluded that Kaizen implementation is stronger, when there is higher extent of:

- the achievement of business goals as the most important measure,

- objectives which are very specific, measurable, achievable, realistic and time-targeted,

- there is a key performance system in place that allows us to monitor and correct our performance in accordance with our objectives,

- goal setting as a tool for making progress of the company,

- goals and objectives which are considered the tool to lead in desired direction of vision, mission, values, and strategy,

- well-defined rules and procedures,

- strict procedures for every single process,

- documented and formalized rules,

- following the procedures,

- following the procedures as the most important task,

- proper care of our employees,

- reward system as mechanism to guide employees to share policy, vision, and mission of the company,

- usage of reward system with monetary prizes,

- usage of reward system with different awards and other recognitions, promotions, reassignments, non-monetary bonuses (e.g., vacations), or a simple thank you,

- reward system which is fair and makes no difference to all employees in the company regardless of the position in the organization,

- not considering conflict as a negative phenomenon but rather opportunity for improvement,

- usage of strategies to limit the negative and to increase the positive aspects of conflict, 
- management of conflicts by using different strategies: avoidance, smoothing, dominance, compromising, or confrontation,

- conflict resolution that involves the reduction, elimination, or termination of all forms and types of conflict by negotiation, bargaining, mediation, or arbitration,

- preference of win-win outcome with mutual benefits to all parties involved in the conflict,

- the most important criteria are knowledge and competitiveness of employees,

- regular planning, execution, and improvement of training program,

- investment in training and professional development of employees,

- employees encouragement for further training and professional development,

- continual learning process with knowledge and competitiveness constantly changed and developed,

- progress and development of employees regularly performed,

- frequently done promotion of employees,

- employee's career development toward both organizational and employee's interest,

- well-structured career development plans for employees that are monitored and evaluated,

- link between progress of our employees and their overall motivation,

- focus on internal processes,

- focus on market, customers and their needs,

- trying to achieve a competitive advantage that enables long-term sustained success,

- trying to optimize business processes across functional and organizational boundaries and

- continuous improvement of processes and emphasis on customer as equally important segments of business development.

Upon Kaizen implementation under above defined circumstances, according to results of this survey, it causes higher performance indicators, especially in the quality field. Accordingly, it is recommended to companies to analyze contextual factors and influence them as much as possible in the proposed manner with aim to reach better performance indicators.

Recommendation for future research in this area is a more detailed analysis on collected data done by using more sophisticated statistical analysis tools, such as regression analysis, structural equations modeling and similar.

\section{ACKNOWLEDGEMENT}

The paper is partially supported by grant from by the Innovation Fund from the budget of the Republic of Serbia from the division of the Ministry of Education, Science and Technological Development, through the Serbia Competitiveness and Jobs Project under contract ID 50138. The authors also thank the respondents who filled out the questionnaires for their kind cooperation.

\section{REFERENCES}

Bateman, N., \& Rich, N. (2003). Companies perceptions of inhibitors and enablers for process improvement activities. International Journal of Operations \& Production Management, 23(2), 185199.

Bessant, J. (2000). Creating and maintaining high involvement innovation. Paper presented at Seminar on Kaizen from Understanding to Action, Institute of Electrical Engineers, London.

De Feo, J. A., \& Barnard, W. (2003). Juran Institute's six sigma: breakthrough and beyond: quality performance breakthrough methods. McGraw-Hill Professional.

Kannan, V.R., Tan, K., Handfield, R.B., \& Ghosh, S. (1999). Tools and Techniques of Quality Management: An Empirical Investigation of Their Impact on Performance. ASQ Quality Management Journal, 6(3), 34-49.

Lagrosen ,S., \& Lagrosen, Y. (2003). Quality configurations: a contingency approach to quality management. International Journal of Quality and Reliability, 20(7), 759-773.

Liker, J. K., Hoseus, M., \& Center for Quality People and Organizations. (2008). Toyota culture. McGrawHill Publishing.

Maarof, M. G., \& Mahmud, F. (2016). A review of contributing factors and challenges in implementing kaizen in small and medium enterprises. Procedia Economics and Finance, 35, 522-531.

Marin-Garcia, J.A., Pardo del Val, M., \& Bonavia, T. (2008). Longitudinal study of the results of continuous improvement in an industrial company. Team Performance Management, 14(1/2), 56-69.

McLoughlin, C., \& Miura, T. (2017). True Kaizen: Management's Role in Improving Work Climate and Culture. Productivity Press.

Mendez, J., \& Vila-Alonso, M. (2018). Threedimensional sustainability of Kaizen. The TQM Journal, 30(4), 391-408.

Merrill P. (2009). Do It Right the Second Time, Second Edition: Benchmarking Best Practices in the Quality Change Process. ASQ Quality Press, Milwaukee.

Pagell, M. (2004). Understanding the factors that enable and inhibit integration of operations, purchasing and logistics. Journal of Operation Management, 22(5), 459-487. 
Peterson, A.J., \& Reid D.R. (1999). Continuous Improvement: Methods and Madness. ASQ's 53rd Annual Quality Congress Proceedings, 218-221.

Spasojević Brkić, V., Klarin, M., \& Ivanović, G. (2009). Influence of Contingency Factors on Application of Quality Tools. FME Transactions, 37, 143-149.

Spear, S., \& Bowen, K.H. (1999). Decoding the DNA of the Toyota Production System. Harvard Business Review, September-October, 95-106.

Tomić, B., \& Spasojević-Brkić, V. (2011). Effective root cause analysis and corrective action process. Journal of Engineering Management and Competitiveness, 1(1/2), 16-20.

Tomic, B., Spasojević Brkić, V., Karapetrovic, S., Pokrajac, S., Milanović, D. D., Babić, B., \& Djurdjevic, T. (2017). Organizational culture, quality improvement tools and methodologies, and business performance of a supply chain. Proceedings of the institution of mechanical engineers, Part B: Journal of Engineering Manufacture, 231(13), 24302442.

Tomić, B., Spasojević-Brkić, V., \& Klarin, M. (2012). Quality management system for the aerospace industry. Journal of Engineering Management and Competitiveness (JEMC), 2(1), 11-15.

Westcott, R.T. (2007). The Certified Manager of Quality / Organizational Excellence Handbook. ASQ Quality Press, Milwaukee.

Womack, J., Jones, D. (2003). Lean Thinking: Banish waste and create wealth in your corporation. New York: Simon \& Schuster.

Yamaguchi, J., \& Kono, H. (2017). Study on standstill conditions in Kaizen activity: Through case studies of two companies in their long-Term efforts. Industrial Engineering \& Management Systems, 16(1), 80-91

\section{KONTEKST IMPLEMENTACIJE KAIZENA I PERFORMANSE}

Unapređenje kvaliteta podrazumeva primenu alata, tehnika, metodologija i aplikacija kvaliteta. Njihovom pravilnom upotrebom moguće je postići željeni nivo kvaliteta, a zatim ga stalno poboljšavati. Primena Kaizena može biti od posebne važnosti. Ovaj rad obuhvata istraživanje koje je sprovedeno u lancu snabdevanja velike multinacionalne kompanije (uzorak od 200 kompanija) i analizira primenu Kaizena i kontekstualnih i performansnih promenljivih korišćenjem korelacione analize. Rezultati istraživanja su pokazali da primena Kaizena u kompaniji pozitivno utiče na pokazatelje performansi, posebno u oblasti kvaliteta. Takođe, primena Kaizena je pozitivno korelirana sa promenljivim kao što su organizacioni ciljevi, nivo formalizacije, sistem nagrađivanja, upravljanje konfliktima i napredak i razvoj zaposlenih.

Ključne reči: Kaizen; Kontekst; Performanse. 